\section{Gregory Carey}

\author{
Human Genetics for the Social Sciences \\ Advanced Psychology Texts, vol. 4 \\ Sage Publications, London 2003 \\ 532 pp.; GBP 37.50 \\ ISBN 0-7619-2345-4
}

Human Genetics for the Social Sciences is an excellent textbook for undergraduate and graduate students to learn about genetics and its application in psychiatric disease and the analysis of variations in normal behavior. There also is much that their teachers will find worthwhile. The text may seem undemanding, but this simply reflects how well Carey knows what he is talking about and how well he conveys this knowledge to the students. In the preface Carey calls the book not a textbook and warns the reader that it does not contain color illustrations or a plethora of text boxes. (This is in contrast to the publisher's recommendations on the back cover which promise highlighted key terms, text boxes and suggested readings at the end of each chapter.) I found the book very enjoyable to read without too much distraction from side bars and text boxes. In addition, Carey has a website that gives all the book's illustrations in color, and that also provides more than excellent learning exercises and practice tests (http://psych.colorado.edu/hgss).

The book is divided into three parts. The first explains at a basic level what cells, genes, DNA, the genetic code and techniques for DNA analysis are. This section concludes with the principles of linkage and association analysis for localizing and identifying genes for monogenic and complex traits. It also includes chapters on genetic regulation, epistasis and Mendelian genetics. Carey advises that the information on Mendelian genetics is probably redundant for most students nowadays. (The redundancy might be a good thing since some tables in this chapter lack the numbers which should teach students how to assign probabilities to e.g. offspring genotypes from different mating types.)

The second part contains five chapters on evolution and evolutionary psychology. This section introduces the forces which influence the genetic makeup of populations (selection, genetic drift, mutation, mating structure and culture). It contrasts the samenessin-behavior approach that characterizes evolutionary psychology with the interest in individual differences that is the raw material for behavior genetics and genetic epidemiology.

The third and last section of the book deals with the genetics of individual differences. It begins with a short description of the basic concepts of variance and correlation. Most social scientists will be familiar with these basic concepts, but is seems a pity that regression and multivariate analysis have not been introduced in this chapter. The next two chapters are on quantitative genetics and introduce her- itability, gene-environment correlation and interaction and genetic and environmental correlations between traits. The methods and assumptions of the twin and adoption design are also explained. The final chapters then summarize the current knowledge on the genetics of IQ, education and social status, and the genetics of personality, schizophrenia and antisocial behavior.

These last chapters go beyond a simple summary of the heritabilities for these traits and emphasize the importance of thinking about mechanisms which might explain the influence of genes on phenotypes. In the chapter on IQ and social status for example, Carey illustrates how one might begin to resolve the question of how genes for IQ influence social status, and possibly thereby the significant heritability of variation in social status. He contrasts the views of Herrnstein and Murray [Herrnstein RJ and Murray C (1994). The Bell Curve: Intelligence and Class Structure in American Life. New York: Free Press] with those of Lewontin et al. [Lewontin RC, Rose S and Kamin LJ (1984). Not in Our Genes: Biology, Ideology and Human Nature, New York: Pantheon] on this issue. Herrnstein and Murray stated in the Bell Curve that society has become more efficient in selecting for IQ. Because IQ is heritable and has a causal influence on social status, society is becoming more and more stratified on the basis of the genes for IQ. Lewontin et al., on the other hand, see the association between IQ and social status as noncausal and mediated by parental advantage. Carey puts both hypotheses into testable models and uses empirical data to show that neither hypothesis is supported by the available empirical data.

Other chapters offer examples of similar approaches. It is a pity that Carey has not included a chapter on the genetics of depression in addition to the ones on schizophrenia and antisocial behavior. In the first part of the book he explains in some detail the cortisol response to stress and how the intracellular cortisol receptor complex influences mRNA transcription. The cortisol hypothesis of depression is an important explanatory model of the stress-depression association and a discussion of this topic would have provided a nice link between the first and last part of the book.

I highly recommend the book to colleagues who teach introductory classes in (behavior) genetics. It is appropriate for a wide audience. Carey's style sometimes is very American, as are some of the examples and jokes, e.g. checking a box to define one's race, taking SAT exams or carrying food in brown paper bags. In the pedigrees that illustrate some of the principles of linkage analysis, the males have names like Zebulon Jones, whereas the females are simply the 'wife of' or Mrs. Jones. This, however, does not detract from the value of the book, which is an excellent resource when teaching behavior genetic courses that go beyond the nature-versus-nurture or genesversus-environment dichotomy.

D.I. Boomsma, Amsterdam

\section{KARGER \\ (C) 2003 S. Karger AG, Basel}

Fax + 41613061234

E-Mail karger@karger.ch

www.karger.com
Accessible online at: www. karger.com/cmg 